\title{
Dyeing of Silk Fabric with Soaked Phaseolus Vulgaris (Red kidney bean) Extract
}

\author{
Debjit Biswas ${ }^{1} \mid$ Goutam Bar ${ }^{1}$
}

1Department of Textile design, National Institute of Fashion Technology, Bhubaneswar, Odisha, India

To Cite this Article

Debjit Biswas, Goutam Bar, "Dyeing of Silk Fabric with Soaked Phaseolus Vulgaris (Red kidney bean) Extract", International Journal for Modern Trends in Science and Technology, 6(9S): 83-88, 2020.

\section{Article Info}

Received on 25-August-2020, Revised on 08-September-2020, Accepted on 12-September-2020, Published on 18-September-2020.

\section{ABSTRACT}

With the rising awareness of sustainability, eco-friendly dyes are preferred over synthetic dyes and chemicals. In our day-to-day life, many natural ingredients have colorant substances but are discarded without efficient use. Similarly, the seeds of Phaseolus vulgaris (Red Kidney Beans) release colorant substances when soaked in water or boiled, but the water is drained out or discarded. The present work aimed to utilize the above extract in a sustainable way. So, an attempt is made to dye the silk fabric with the colorant extract with various mordants at different temperatures. The colorant was extracted by soaking Red Kidney Beans for 3 hours and further boiling it for 20 minutes at $100^{\circ} \mathrm{C}$. Degummed and bleached Mulberry silk fabric was dyed with the colorant extract at $90-95^{\circ} \mathrm{C}$ and $\mathrm{pH}[3,3.5,4,4.5,5,5.5]$ for 45 minutes. Dyed fabric samples were tested for color strength using color i7 Spectrophotometer. Also, the dyed fabric samples were tested for different color fastness properties (colourfastness to washing, water, rubbing, light etc.) and mechanical properties (thickness, bending length, flexural rigidity, crease recovery). Satisfactory results were found. Thus, the implications of the research show a promising future for dying of silk fabric with a sustainable approach.

Keywords: Red Kidney Beans extract, Silk fabric, Dyeing, Natural dyeing, Eco friendly dye

\section{INTRODUCTION}

Over the years, the textile industry has a huge consumption of synthetic dye due to its wide range of bright shades, cheaper price, and better fastness properties in comparison to natural dyes. The production of synthetic dye includes petrochemical sources therefore some of the dyes contain carcinogenic amine. So, application of such dyes is dangerous to health and is also a reason for imbalance of the ecosystem. Recently, due to increased environmental awareness the demand for natural dyes is increasing as they are non-toxic, renewable, biodegradable and provide large shades with good color fastness properties [1,2,3].Natural dyes have been used since ancient times. They are extracted from natural sources like parts of the plant such as roots, barks, leaves, fruits and flowers and are applied on the fabric with mordant for better color fixation and to enhance the shade depth [2]. Moreover, India is known for its rich biodiversity of flora. Thus, this rich biodiversity contributes to a huge number of diverse natural products, including natural dye [4]. Natural dyes are majorly applied on natural fibers like wool, cotton and silk [2,3]. Some natural dyes show functional properties such as antimicrobial and medicinal property. Also, some natural dyes absorb in the Ultraviolet region. Thus, fabric dyed with such natural dyes results in good protection from UV light [3]. These additional values of natural dye 
are resulting in an increased use of natural dye in many small and medium-scale industries, to give a sustainable end product. The consumption of such products is increasing in national and international markets with rising awareness about sustainability [4]. Therefore, with the rising demand of natural dye the present study is aimed on the application of eco-friendly natural colorant extract released by soaked Red kidney bean (Phaseolus Vulgaris L.) on textile material.

Kidney bean (Phaseolus vulgaris L.) is the world's second largest important bean in terms of production and consumption $[5,6]$. Figure 1 shows the image of the Red kidney bean. The kidney beans are rich in protein (possess essential amino acid) carbohydrates, minerals and vitamins. There are many varieties of kidney bean available in terms of their size, shape, density and color. Kidney beans are found in black, red, white and brown color. This variation in color is due to the presence of pigment. Red kidney bean seed coat contains Anthocyanins pigment $[6,7]$. Anthocyanin is a water-solublephenolic pigment found in different parts of the plant. Figure 2 shows the structure of basic anthocyanin compound. Anthocyanins have some significant properties such as antioxidant and antimicrobial activity.Anthocyanins are also used in food, pharmaceutical and cosmetic industries.[8]. Color stability of anthocyanin is affected by their chemical structure and $\mathrm{pH}$ [7]. The red-colored pigments of anthocyanins are due to the presence of flavylium cations $[9,10]$. It was observed that on soaking the red kidney bean, it releases a huge amount of red colorant. Also, it was noted that the concentration of the colorant increases with an increase in duration of soaking. Therefore, the study is aimed to dye the silk fabric with the leftover red kidney bean extract in a sustainable way.

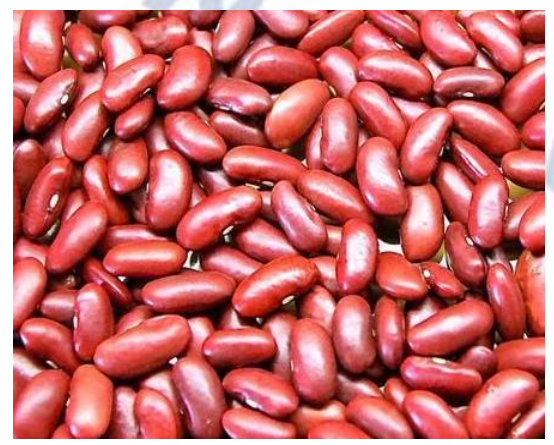

Figure1 Red Kidney Bean<smiles></smiles>

Figure 2 Structure of Anthocyanin[10]

\section{EXPERIMENT}

\section{Materials}

A 40 GSM silk habutai plain woven fabric was sourced from the local fabric market of Bhubaneswar, India having ends/ inch and picks/inch 120 and 104 and warp and weft yarn count 22 and 55 denier, respectively. Red kidney bean, Alum and Lemon juice was sourced from the local market of Bhubaneswar, Odisha, India.

\section{Colorant extraction from Red kidney bean in aqueous medium}

For the extraction process, initially the red kidney bean was washed with running water and was soaked for 3 hours. Further the kidney beans were boiled at $100^{\circ} \mathrm{C}$ with a material to liquor ratio of $1: 5$ for 20 minutes.

\section{Application of dyes}

The degummed and bleached fabric samples were dyed with the red kidney bean extract. Extracted solutions were used directly without any dilution, having material to liquor ratio $1: 100$ in two different methods. In method I, dyeing was carried out with Alum as a mordanting agent. Alum was used in different concentrations (15gpl, $20 \mathrm{gpl}, 25$ gpl, $30 \mathrm{gpl}, 35 \mathrm{gpl}$ and $40 \mathrm{gpl}$ ). In method II, dyeing was carried in different acidic $\mathrm{pH}(5.5,5,4.5,4,3.5$ and 3 ) out without any mordanting agent. Acidic $\mathrm{pH}$ was maintained using citric acid i.e. lemon juice. Dyeing was carried out in a paramount water bath for $45 \mathrm{~min}$ at $90-95^{\circ} \mathrm{C}$. Dyed samples were rinsed with cold and hot water to remove the superficial colorants. Total 12 samples were developed as per the condition mentioned in Table 1. 
Table 1 Sample No according to concentration of Alum and $\mathrm{pH}$ of the dye bath

\begin{tabular}{ll|ll}
\hline Sample No. & $\begin{array}{l}\text { Concentration of Alum } \\
\text { (gpl) }\end{array}$ & SampleNo. & Dye bath pH \\
\hline A & 15 & A1 & 5.5 \\
B & 20 & B1 & 5 \\
C & C1 & 4.5 \\
D & 25 & D1 & 4 \\
E & 30 & E1 & 3.5 \\
F & 35 & F1 & 3 \\
\hline
\end{tabular}

Note: gpl-Gram per litre

\section{Treatment of dyed samples}

Silk fabric sample dyed with kidney bean extract was treated with different $\mathrm{pH}$ aqueous solutions. Four solutions were prepared having $\mathrm{pH} 3,5,8$ and 10. $\mathrm{pH}$ of the solutions were measured by a digital $\mathrm{pH}$ tester. Acidic solutions were prepared using acetic acid and Alkaline $\mathrm{pH}$ solutions were prepared using Sodium Carbonate. A dyed sample was cut into 5 pieces and out of which 4 samples were dipped for 5 minutes into four different $\mathrm{pH}$ solutions prepared earlier. One sample was kept for further reference. Later samples were air dried and tested for their color strength.

\section{MEASUREMENT}

\section{Color strength}

The conditioned and dyed silk fabric samples are scanned by spectrophotometer model no Color i7 made by Gretag Macbeth, USA, using MAV (10 mm) aperture with specular reflection included $\left(10^{\circ}\right.$ observer, D65 illuminant). Calorimetric values ( $\mathrm{L}^{*}$, $a^{*}, b^{*}, C, h^{\circ}$ and $\mathrm{K} / \mathrm{S}$ ) of these samples are measured as per the AATCC Testing method 173-1998. At the time of measurement, dyed samples are folded into four layers and mounted firmly over the aperture to measure the reflectance. The colour strength of the dyed silk fabric samples is expressed as $\mathrm{K} / \mathrm{S}$ value. $\mathrm{K} / \mathrm{S}$ value is measured by the reflectance value of light from the sample by Kubelka Munk Equation:

$\mathrm{K} / \mathrm{S}=(1-\mathrm{R})^{2} / 2 \mathrm{R}$

Where $\mathrm{K}, \mathrm{S}$ and $\mathrm{R}$ are the absorption, scattering coefficients and Reflectance Value respectively[11].

\section{Fastness properties}

Silk fabric samples dyed with kidney bean extracts were tested for their color fastness properties. Washing fastness of the samples were tested in a launder-o-meter following ISO $105 \mathrm{C06}$ test method at $50^{\circ} \mathrm{C}$ for $45 \mathrm{~min}$ with 5 gram per litre non-ionic detergent. Color fastness to water of the dyed silk fabrics were tested following ISO 105 E01 test method. Colourfastness to Crocking was tested using Paramount digital crock meter according to ISO $105 \mathrm{X} 12$ test method. The change in color and the staining on the white materials were accessed by AATCC grey scales. Color fastness to light of the dyed samples were tested according to ISO 105 B02 test method and the tested samples were assessed for change in color by AATCC blue wool scale.

\section{Mechanical Properties}

Silk fabric dyed with kidney bean extracts were tested for their mechanical properties like thickness, bending length, flexural rigidity and crease recovery using fabric thickness gauge, paramount Stiffness tester and crease recovery tester of paramountunder standard atmospheric condition.

\section{RESULTS AND DISCUSSION \\ Color strength of dyed samples}

The silk fabric samples dyed with red kidney bean extracts were tested for their color strength on spectrophotometer. Calorimetric values $\left(\mathrm{L}^{*}, \mathrm{a}^{*}, \mathrm{~b}^{*}\right.$, $\mathrm{C}^{*}, \mathrm{~h}^{\circ}$ and $\mathrm{K} / \mathrm{S}$ ) of the silk fabric samples dyed as per method I and Method II are tabulated in Table 2 . Color strength Value $(\mathrm{K} / \mathrm{S})$ indicates that there is no major impact of alum concentration on color strength. Similarly, Color strength is not affected also by higher acidic $\mathrm{pH}$ of the dye bath. Wavelength-reflectance curve is also shown the same in figure 3 and figure 4 . Color strength data also reveals that samples dyed in acidic $\mathrm{pH}$ have higher color strength compared to the samples dyed with alum. However, for absorption and fixation of color either alum or acidic $\mathrm{pH}$ is required during the dyeing. Figure 5 shows the color spectrum of the samples dyed with alum and acidic $\mathrm{pH}$ respectively. 
Table 2 Colorimetric values of silk fabric samples dyed with Red Kidney bean extract

\begin{tabular}{ccccccc}
\hline $\begin{array}{c}\text { Sample } \\
\text { No }\end{array}$ & $\mathrm{L}^{*}$ & $\mathrm{a}^{*}$ & $\mathrm{~b}^{*}$ & $\mathrm{C}^{*}$ & $\mathrm{~h}^{\circ}$ & $\mathrm{K} / \mathrm{S}$ \\
\hline A & 62.53 & 12.01 & 15.32 & 19.46 & 52.62 & 9.76 \\
B & 60.66 & 12.21 & 15.45 & 19.69 & 52.55 & 8.83 \\
C & 62.45 & 11.9 & 15.11 & 19.23 & 52.58 & 9.93 \\
D & 64.15 & 11.02 & 13.91 & 17.75 & 52.55 & 10.83 \\
E & 61.29 & 11.36 & 14.62 & 18.52 & 52.71 & 9.27 \\
F & 61.42 & 11.32 & 14.72 & 18.58 & 52.8 & 9.27 \\
A1 & 66.1 & 12.1 & 12.33 & 17.28 & 46.97 & 12.47 \\
B1 & 65.63 & 12.17 & 12.87 & 17.72 & 47.3 & 12.05 \\
C1 & 63.89 & 12.68 & 13.62 & 18.64 & 47.43 & 10.93 \\
D1 & 66.5 & 12.33 & 13.41 & 18.21 & 47.55 & 12.36 \\
E1 & 62.77 & 13.53 & 15.46 & 20.54 & 48.03 & 10.37 \\
F1 & 63.27 & 13.1 & 15.1 & 19.99 & 48.11 & 10.18 \\
\hline
\end{tabular}

Note: $\mathrm{L}^{*}$ value of lightness and darkness, $\mathrm{a}^{*}$ value of red and green, $\mathrm{b}^{*}$ value of yellow and blue, $\mathrm{C}^{*}$ valueof chroma, $h^{\circ}$ value of hue

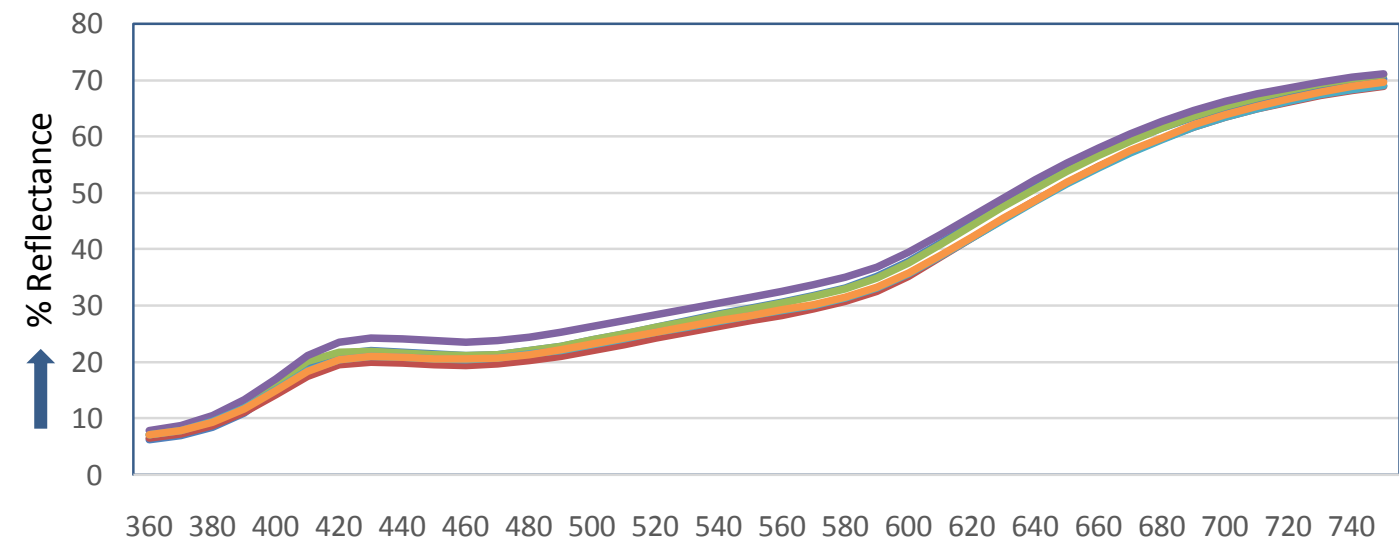

$\rightarrow$ Wave length $(\mathrm{nm})$

Figure 3 Wavelength- reflectance curve of silk fabric dyed with red kidney bean extract with Alum

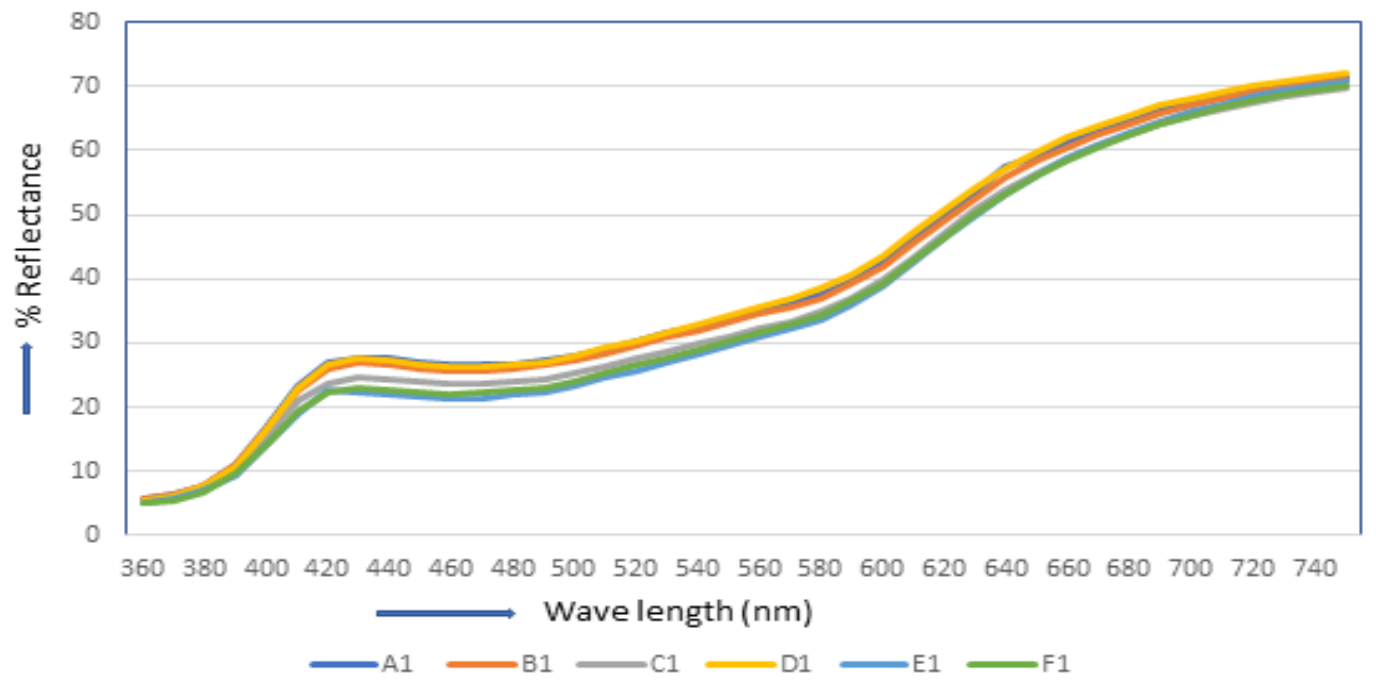

Figure 4 Wavelength- reflectance curve of silk fabric dyed with red kidney bean extract in different acidic $\mathrm{pH}$ 


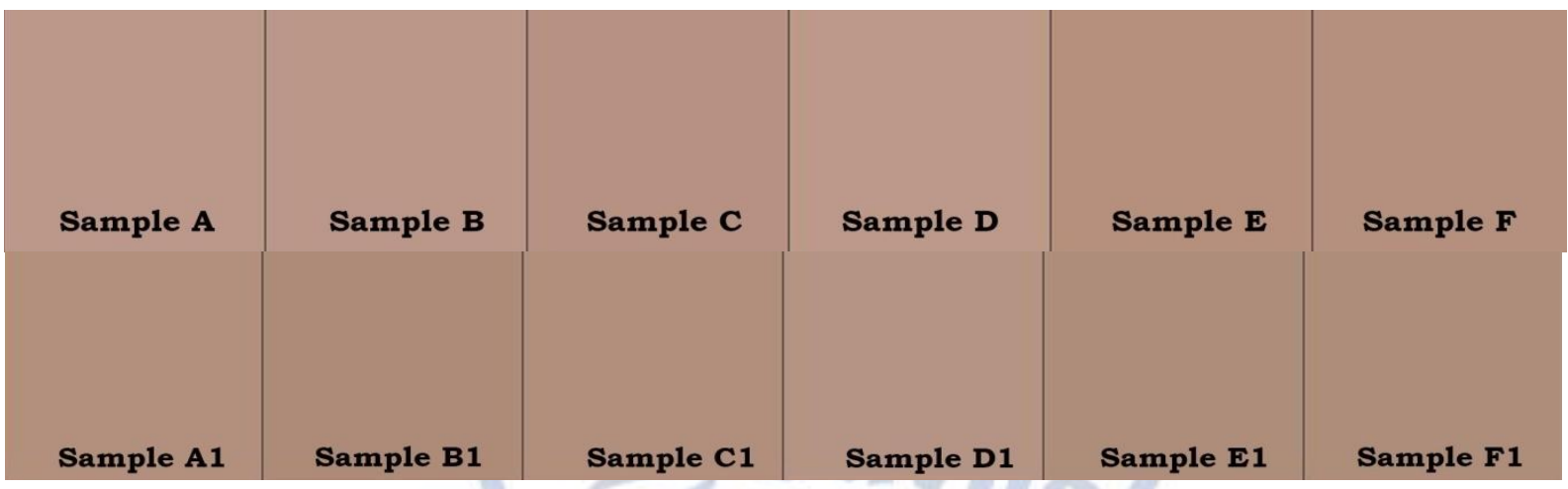

Figure 5 Color spectrum of dyed silk fabric sample with Red Kidney bean extract (spectrophotometer images)

\section{Effect of $\mathbf{p H}$ on color strength}

Sample B1 was selected randomly to check the effect of $\mathrm{pH}$ on color strength. Calorimetric values of the dyed silk fabric sample treated with different $\mathrm{pH}$ aqueous solutions are tabulated in Table 3. The Color strength Value $(\mathrm{K} / \mathrm{S})$ indicates that no major effect of $\mathrm{pH}$ on the dyed sample. The color strength value also reveals that dyed samples in basic $\mathrm{pH}$ have higher color strength than the fabric dyed at acidic pH. Figure 6 shows color spectrum of the the effect of $\mathrm{pH}$ on the dyed samples.

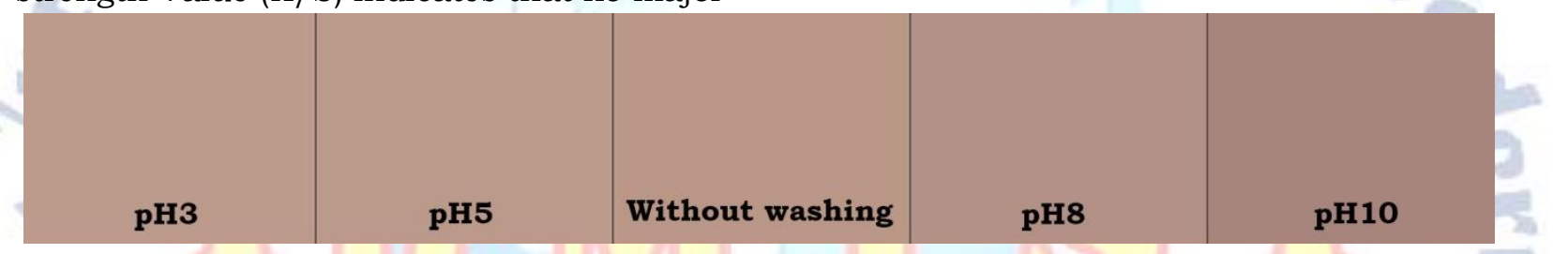

Figure 6Color spectrum of dyed silk fabric sample with Red Kidney bean extract at acidic $\mathrm{pH}$, tested for effect of $\mathrm{pH}$ on color strength (spectrophotometer images)

Table 3 Colorimetric values of dyed silk fabric treated with different $\mathrm{pH}$ solution

\begin{tabular}{ccccccc}
\hline $\begin{array}{c}\text { Washing } \\
\text { Condition }\end{array}$ & $\mathrm{L}^{*}$ & $\mathrm{a}^{*}$ & $\mathrm{~b}^{*}$ & $\mathrm{C}^{*}$ & $\mathrm{~h}^{\text {* }}$ & $\mathrm{K} / \mathrm{S}$ \\
\hline pH 3 & 67 & 11.56 & 12.72 & 17.19 & 48.58 & 11.92 \\
pH 5 & 66.43 & 11.86 & 12.39 & 17.16 & 48.15 & 11.96 \\
Without washing & 65.63 & 12.07 & 13.25 & 17.93 & 48.55 & 12.05 \\
pH 8 & 63.58 & 12.52 & 11.42 & 16.83 & 46.88 & 12.56 \\
pH 10 & 68.57 & 12.64 & 10.31 & 16.32 & 46.14 & 12.85 \\
\hline
\end{tabular}

\section{Fastness properties}

Four samples (E, F, E1 and F1) were selected randomly for testing of their fastness properties out of the 12 samples. Table 5 illustrates the color fastness properties of silk fabric samples dyed with red kidney bean extract. Test results indicate that in all samples there is a little change in color in case of color fastness to washing. This is due to the presence of anthocyanin, the colorant, which is $\mathrm{pH}$ sensitive. Alkaline $\mathrm{pH}$ changes the color of the dyed samples during washing. All the samples exhibit excellent results against colourfastness to water and crocking. Samples were also shown to have very promising results in case of color fastness to light.

Table 4 Color fastness properties of silk fabrics dyed with Red Kidney bean extract

\begin{tabular}{|c|c|c|c|c|c|c|c|}
\hline \multirow[t]{2}{*}{$\begin{array}{l}\text { Sample } \\
\text { number }\end{array}$} & \multicolumn{2}{|c|}{$\begin{array}{c}\text { Color fastness } \\
\text { towashing }\end{array}$} & \multicolumn{2}{|c|}{$\begin{array}{c}\text { Colorfastness to } \\
\text { water }\end{array}$} & \multicolumn{2}{|c|}{$\begin{array}{c}\text { Colorfastness } \\
\text { to crocking }\end{array}$} & \multirow[t]{2}{*}{$\begin{array}{c}\text { Colorfastness } \\
\text { to light }\end{array}$} \\
\hline & $\begin{array}{l}\text { Color } \\
\text { change }\end{array}$ & $\begin{array}{l}\text { Staining } \\
\text { on wool }\end{array}$ & $\begin{array}{l}\text { Color } \\
\text { change }\end{array}$ & $\begin{array}{l}\text { Staining } \\
\text { on wool }\end{array}$ & Dry & Wet & \\
\hline $\mathrm{E}$ & 4 & $4-5$ & $4-5$ & 4 & 5 & $4-5$ & 6 \\
\hline
\end{tabular}




\begin{tabular}{cccccccc} 
F & 4 & $4-5$ & $4-5$ & 4 & 5 & $4-5$ & 6 \\
E1 & $3-4$ & $4-5$ & $4-5$ & 4 & $4-5$ & 4 & 7 \\
F1 & 4 & $4-5$ & $4-5$ & 4 & $4-5$ & $4-5$ & 7 \\
\hline
\end{tabular}

\section{Mechanical properties}

Silk fabric samples dyed with Red Kidney bean extract were tested for their compression and bending properties as recorded in Table 6 . Testing was done on randomly selected four samples (E, F, $\mathrm{E} 1$ and $\mathrm{F} 1$ ). The test result reveals that the bending length and flexural rigidity of the fiber has no major changes after dyeing. Also, the crease recovery of the fibers does not show much significant changes.

Table 6 Compression and bending properties of silk fabric after dyeing

\begin{tabular}{cccccccccc}
\hline $\begin{array}{c}\text { Sample } \\
\text { No }\end{array}$ & $\begin{array}{c}\text { Surface } \\
\text { thickness } \\
(\mathrm{mm})\end{array}$ & $\begin{array}{c}\text { Fabric } \\
\text { weight } \\
\left(\mathrm{g} / \mathrm{cm}^{2}\right)\end{array}$ & \multicolumn{2}{c}{$\begin{array}{c}\text { Bending } \\
\text { length }(\mathrm{cm})\end{array}$} & \multicolumn{2}{c}{$\begin{array}{c}\text { Flexural } \\
\text { rigidity } \\
(\mathrm{mg} \mathrm{cm})\end{array}$} & \multicolumn{2}{c}{$\begin{array}{c}\text { Crease } \\
\text { recovery } \\
\text { angle (degree) }\end{array}$} \\
\hline & & & Warp & Weft & Warp & Weft & Warp & Weft \\
\hline $\begin{array}{c}\text { Control } \\
\text { Fabric }\end{array}$ & 0.09 & 0.0038 & 1.92 & 2.01 & 26.90 & 30.86 & 99 & 109 \\
$\mathrm{E}$ & 0.10 & 0.0039 & 1.80 & 1.97 & 22.74 & 29.82 & 93 & 105 \\
$\mathrm{~F}$ & 0.10 & 0.0039 & 1.84 & 1.99 & 24.30 & 30.73 & 91 & 106 \\
$\mathrm{E} 1$ & 0.10 & 0.0039 & 1.90 & 2.05 & 26.75 & 33.60 & 100 & 110 \\
$\mathrm{~F} 1$ & 0.10 & 0.0039 & 1.93 & 2.03 & 28.04 & 32.63 & 98 & 112 \\
\hline
\end{tabular}

\section{CONCLUSION}

The left-overcolorant extract Red Kidney bean can be a good source of natural dye.The silk fabric can be dyed using alum as a mordant or in acidic $\mathrm{pH}$.The test resultreveals that the samples dyed in acidic $\mathrm{pH}$ has higher color strength than Alum. All the samples show excellentresults against colorfastness to water and crocking. Also, shows satisfactory results in case of colorfastness to light.Thus, the findings are fulfilling the objective of the study that the waste water extract of Red Kidney bean can be efficiently used. It has the potential for good dyeability of silk fabrics.

\section{ACKNOWLEDGEMENT}

Authors are thankful to Mr. Krushna Chandra Gilli, Laboratory Assistant, Textile Design Department, National Institute of Fashion Technology, Bhubaneswar for extending support to carry out the dyeing and testing of dyed samples.

\section{REFERENCES}

[1] A. Karuppuchamy and G. Annapoorani, "Natural Dye Extraction from Agro-waste and its Application on Textiles". Asian Dyer. vol. 16, 2019, pp. 35-39.

[2] G. Bar and M. Bar, (2020). "Dyeing and flame-retardant finishing of silk fabric: an eco-friendly approach". SN Applied Sciences, vol. 2(3), 2020, pp. 1-9.

[3] L. Amanuel, D. Adefris, E. Ajaw, N. Bekele and A. Abinet, "Dye Extraction and Cotton Dyeing from Peach Leaf". Current Trends in Fashion Technology \& Textile Engineering, Juniper Publishers Inc., vol. 5(3), 2019, pp. 68-74.

[4] R. Siva, "Status of natural dyes and dye-yielding plants in India.” Curr. Sci. Vol. 92, 2007,
[5] I. A. Wani, D. S. Sogi, A. A. Wani and B. S. Gill, "Physical and cooking characteristics of some Indian kidney bean (Phaseolus vulgaris L.) cultivars". J. Saudi Soc. Agric. Sci., vol. 16(1), 2015, pp. $7-15$.

[6] M. G. Choung, B. R. Choi, Y. N. An, Y. H. Chu and Y. S. Cho, "Anthocyanin profile of Korean cultivated kidney bean (Phaseolus vulgaris L.)," J. Agr. Food Chem., vol. 51(24), 2003, pp. 7040-7043.

[7] L. Mojica, M. Berhow and E. G. D. Mejia, "Black bean anthocyanin-rich extracts as food colorants: Physicochemical stability and antidiabetes potential". Food Chemistry, 229, 2017, pp. 628-639.

[8] A. Cisowska, W. Dorota and B. A. Hendrich, "Anthocyanins as Antimicrobial Agents of Natural Plant Origin". Nat Prod Commun. Vol. 6, 2011. pp. 149-56.

[9]H. E. Khoo, A. Azlan, S. T. Tang and S. M. Lim, "Anthocyanidins and anthocyanins: colored pigments as food, pharmaceutical ingredients, and the potential health benefits" Food Nutr. Res., vol. 61(1), 2017, pp. 1-21.

[10] D. Dabas, "Polyphenols as Colorants." Adv. Food Technol. Nutr. Sci. Open J., vol. SE(2), 2018, pp. S1-S6.

[11] D. Ganguly, C. Mondal and A. K. R. Choudhury, "Application of syntan and sodium sulphate to improve the solid dyeing effect of wool-silk blends dyed with milling type acid dyes". Research Journal of Textile and Apparel. vol. 21(3), 2017, pp. 219-238. 